\title{
College English Teaching Reform Based on MOOC Course
}

\author{
Peng Yifei ${ }^{1}$ \\ ${ }^{1}$ Henan Institute of Economics and Trade, Zhengzhou City, Henan Province, 450018
}

Keywords: MOOC course; Operating Mechanism; College English; Teaching Reform

\begin{abstract}
MOOC is the abbreviation of the Massive Open Online, and the reason why it is popular in the world is that it is a new concept of education in accordance with the trend of global education information. MOOC course education mode is not only a challenge to the traditional college English teaching, but also provides a new angle of view for the development of College English, becoming a new pivot for leveraging the College English teaching reform. Based on the author's teaching experience for many years, this paper first analyzes the operation mechanism of MOOC course, and then discusses the impact of MOOC course on College English curriculum reform, and finally puts forward the strategies of College English Teaching reform based on MOOC course.
\end{abstract}

\section{Introduction}

As a large-scale public online course, the emergence of MOOC course will have a huge impact on English Teaching in higher vocational colleges. Since most MOOC course are taught in English, it will greatly promote the integration of English basic knowledge and professional English knowledge, so as to provide students with a good professional English language environment and the opportunity to continue education. In view of this, it is necessary to introduce the MOOC course in Higher Vocational English education, combined with the requirements of Vocational College English syllabus, relying on the MOOC course to reform the Vocational English course and examination mode.

\section{Operation Mechanism of MOOC Course}

First, the advanced educational technology provides the possibility for educational innovation. From the initial topic to the final getting on line, MOOC course involves a multiple operational elements, such as instructors, teaching assistants, video tapes, instructional designers, IT specialists, platform specialists, operation teams and project managers. In addition, instruction also involves asynchronous access to video, online forums, other learning materials, testing and other assessments.

Second, in the teaching method, it has changed the traditional teaching mode, and through the construction of the network teaching system, the passive learning for students becomes active learning, interactive learning, inquiry learning, collaborative learning, mobile learning and personalized learning, gradually it becomes a reality.

Third, the application of intelligent teaching evaluation technology and peer assessment are the two main ways of courses MOOC evaluation. To conduct the study evaluation to the learner groups which has a large number of people and the learning degree difference is very high is hard to finish. In addition to intelligent evaluation tools, MOOC course platform is also designed to allow learners to actively participate in the evaluation of the function, so that learners are not only the course of consumers, but also the participants and builders of the curriculum. 
Fourth, MOOC course uses a single thread and multi thread combination of learning sequence. At present, most of MOOC course is the teaching mode of single thread, that is, from the beginning of the first knowledge of the course, to learn sequentially, after finishing, mastering, it can continue learning assessment through a knowledge point. Other courses are to take the way of multi thread, and it does not need to be strictly to learn in order, and students can freely choose the course of knowledge content according to their own actual situation. Single thread of teaching way can ensure knowledge structure clarity and logic, the deficiency is lack of flexibility; multi thread mode of teaching is that the students have a more flexible choice and it can improve the speed and efficiency of learning.

Fifth, MOOC course does not adapt the course scheduling, and it can start a network course at any time and each section of class teaching time is more flexible. And each section of class teaching time is more flexible, general in 5 - 20 minutes, no more than 30 minutes. A course usually can be learned within a few weeks.

\section{The Influence of MOOC Course on the Reform of College English Course}

To strengthen the social function of College English. Traditional college English class is mainly for the college students, and the number is limited; The MOOC course is an online course, and learners come from around the world, all walks of life, and the number of registered students are often thousands. Therefore, MOOC course model will break the wall limit of College English, extend the education object of College English curriculum, making the College English education can be got everywhere and give full play to its social function.

To strengthen the systematic and scientific study of English teaching. College English is a kind of humanistic education, and the research on English teaching is mainly qualitative, quantitative and complementary. In the teaching process, course MOOC will automatically generate a lot of big data, through mass data analysis, the teaching can track learners' course, such as the learning time of each knowledge point, learning frequency and job completion, with these, teachers analyze the law of the gathering of education, improve the teaching content and methods.

To pay attention to the value of College English education. Course MOOC model expands the educational object, therefore, the College English teaching plan will no longer be the traditional model, in MOOC course mode, learners can learn the course according to the needs of the free, but if you want to get a certificate, it needs to pay. This is the part of value-added education in MOOC course model. Therefore, the post College English era will be a English for specific purposes (ESP), ESP teaching will be a combination of College English and professional, and it is more able to meet the needs of social and personalized, and it will increase the value of education.

To promote the construction of the network platform and the popularization of the network teaching. First of all, MOOC course will change the traditional classroom teaching. MOOC course is a kind of network teaching, so the learner is not limited by time and place restrictions, as long as having access to the Internet and the surfing in Internet, their learning can be carried out at any time and place, that is, mobile learning. Secondly, MOOC course is also different from the network video open class teaching. As an online course, it can be said that MOOC course is an upgraded version of the online video open class, and it integrates a large number of Internet tools (such as YouTube), and combines with the most common social networking platform Twitter, Facebook, which is more in line with the interpersonal communication habits of twenty-first Century. After learning each time, the learners can interact with teachers and other learners through the course MOOC platform to promote learning.

To promote the construction of the relationship between teachers and students under the 
new teaching mode. Although the traditional English teaching has been put forward the a student centered teaching slogan in the classroom process, teachers are still in the dominant position in the teaching content, teaching methods, examination results and other aspects. In MOOC course mode, the relationship between teachers and students is more equal. Students can choose several courses to learn according to their own learning objectives and "certificate" requirements. University teachers will also pay more attention to the learning of knowledge feedback, more online communication with students to discuss, and to improve the teaching of courses based on feedback.

\section{College English Teaching Reform Strategies Based on MOOC Course}

Scientifically Form a Macro Planning of MOOC Course. The reform of College English belongs to the category of educational reform, and the reform needs to make a reasonable strategic plan. From the macro level, in the post College English, English curriculum reform should be based on the guaranteeing of educational equity, improving the quality of education, deepening curriculum reform, improving education management and promoting technological innovation and other basic mission. All learners have equal and appropriate learning opportunities, by leveraging digital teaching and learning tools, networking curriculum center platform management system, constructing digital learning environment and other measures to stimulate the potential of English education.

Comprehensively training teachers ability in MOOC course curriculum reform. Teachers are the executor of education, to strengthen teacher training, promote the combination of information technology and teaching, is the basis and power of the reform of College English MOOC course. Training mode can be carried out by occasional seminars, research information technology and combination of different teaching strategies, and then focus on training.

Reasonably to construct the new college English MOOC course curriculum system. First, clear curriculum value, analyze curriculum objectives, adjust curriculum structure. In the post College English era, College English should be combined with each other to highlight the ESP teaching, and increase the value of the English curriculum to meet the individual needs. Foreign Language Institute of Fudan University, Professor Cai Jigang believes that ESAP pays attention to the content of a subject area, such as medical English, biological English, financial English, etc., but due to the lack of corresponding professional knowledge, College English teachers should not go to this kind of professional English, and paying attention to the EGAP curriculum mainly trains interdisciplinary academic oral communication ability and academic communication skills. In course MOOC mode, the most intuitive test standard is the number of learners, the number of times and the number of completed courses discussed in the course. Second, determine the curriculum system under the sub curriculum and outline the logical relationship between the curriculum. In the extension of the same course series, it may involve the same professional multiple courses, and course content and may exist overlap, interrelated parts. More complex, some of which may be related to cross disciplinary. English is a large class of courses, can be divided into different classes, such as listening, speaking, reading, writing, translation, grammar, vocabulary and other different classes, therefore, it is very important for the whole course system to combine the curriculum value, the curriculum goal, and the outline of the logical relation of each course or knowledge in the curriculum system. Third, effectively cut the sub-course knowledge, clarify the degree of difficulty of knowledge points. Different from the traditional 45-minute lessons per class, MOOC course having the micro-lesson feature, each video only 10 minutes, only telling a point. At the same time, setting between knowledge micro lesson is like the game levels, and learners must complete an order to enter the next level. Therefore, the level should be easy to difficult, progressive layers. 
Inheritance and cohesion between the various knowledge points is very clear, constituting a complete and progressive knowledge.

\section{Conclusion}

Large-scale promotion of online courses always makes everyone in the learning state. The teaching reform of teacher education programs needs to make full use of information technology to provide pre-service teachers a broader, more open, more real learning opportunities and platform. Through the integration of technology and classroom teaching, it can promote pre-service teachers' professional development in all directions. Meanwhile, by curriculum development, teachers change instruction and student concept, placing themselves in the discipline, curriculum, which can accelerate their own professional development.

\section{References}

[1] Huo Hong, Liu Yan. A preliminary study on Vocational English teaching reform in Higher Vocational Colleges under the background of MOOC course [J]. vocational and technical education, 2014,08:43-45.

[2] Chen Shiqing. MOOC course Enlightenment to the reform of basic English education in China [J]. Journal of Foreign Language College of Shandong Normal University (Basic English Education), 2014,03:3-8.

[3] Wang Shouhong, Liu Jinling. Research on ESP teaching mode of College English based on content in the context of course [J]. National audio-visual education, 2015,04:97-101+120.

[4] Zhang Mulin, Sun Xiaojun. Based on MOOC course of the flipped classroom teaching mode -- a follow-up College English curriculum for cases [J]. Modern educational technology, 2015,08:81-87.

[5] Zhang Dianen. Design and practice of oral English course MOOC -- a case study of "course MOOC 900" English [J]. Foreign language world, 2015,04:90-96. 